\title{
Changes in the Korean Government's HR System and in the Education of Government Officials
}

\author{
In Pyo-Hwang* \\ Professor at the National Human Resources Development (NHI) under the Ministry of Personnel Management,
} Korea

*Corresponding Author: In Pyo-Hwang, Professor at the National Human Resources Development (NHI) under the Ministry of Personnel Management, Korea

\begin{abstract}
The Korean civil service in terms of human resource strategy are being currently incapable of continuing success in a rapidly changing environment.

As such, this paper addresses the process of establishing the system dynamic approach for consistent HRD management with some theoretical background. To do this, the development situation of public service system in Korea and new national civil service education system are discussed.

Based on that, major directions for civil service education programs in the future are shown as; Enhancing education on public service values, restructuring training system at central government, with specific strategic approach of the e-learning system.

Lastly, some implication thru conclusion and implementations are given.

Keywords: Civil Service, HRD (Human Resource Development), Education \& Training, E-Learning
\end{abstract}

\section{INTRODUCTION}

The traditional Korean civil service was recently incapable of continuing success in a rapidly changing environment, i.e. unexpected economic situation, newly required need etc. As a consequence, the Korean government initiated urgent government reforms to enhance competencies and to create a more competitive workforce, based on a principle of the new public management.

In 2006, the Korean government ${ }^{1}$ introduced major competency management program for the training and further development of its own workforce. In the side of importance of human resource development (HRD) in public sector, its role to cope with change was emphasized. As a result, HRD system in the Korean public sector became to be the core of government competitiveness, as the administrative environmental changes.

This paper will address the process of establishing the system dynamic approach for consistent HRD management at the governmental level and with an analysis of related theoretical background, and to recognize whether it has had a beneficial influence on the national human resource management strategy. To do this, the development situation of public service system in Korea and new national civil service education system are discussed.

Furthermore, with directions for civil service education programs in the future, as an implication, some challenges encountered and expected benefits are considered as well.

\section{SySTEM DYNAMIC APPROACH FOR CONSISTENT HRD MANAGEMENT}

Human Perfect Working Systems (HPWS) involving a specific set of practices aimed at: increasing the quality of human capital by raising employee knowledge, skills and abilities; motivating employees to contribute greater discretionary effort; and empowering them to help deliver business goals and objectives, appearing to affect firm performance positively (Bacon, 2015).

HPWS which includes public sector is a specific combination of human resources practices, work structures, and processes that maximizes employee knowledge, skill, commitment, and flexibility.

\footnotetext{
${ }^{1}$ The Civil Service Commission (CSC) was then the central personnel agency in Korean government 
Also HPWS is system composed of many interrelated parts that complement one another to reach the goals of an organization, large or small (Figure 1) (Snell, 2014).

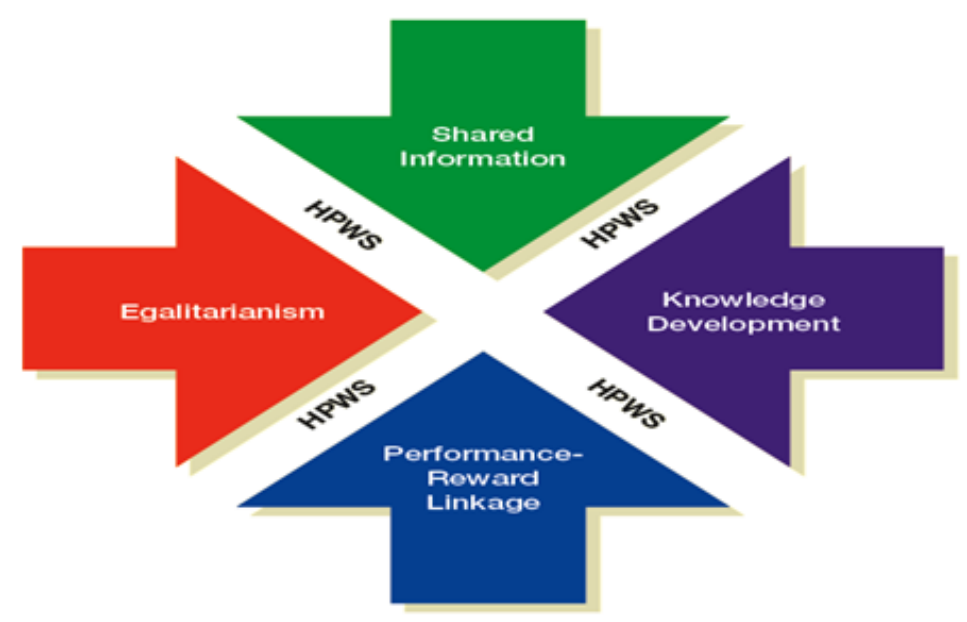

Fig1. High Performance Work System

Based on approaches such as HPWS concept, the behavior of the system is strongly influenced by the structure of interacting feedback loops inside the closed boundary.

According to Richardson (1991), there are roughly seven stages in approaching a problem from the system dynamics perspective. Based on this respective, a system dynamic conceptual framework for human resource development is able to be made of;

a. Understanding of human resource (HR) system, b. Problem identification, c. Learning conceptualization, d. Model formulation, e. Simulation application, f. Policy analysis, g. Policy Implementation.

The process begins and ends with understandings of human resource (HR) system and its problem identification, so it forms a loop, not a linear progression. Figure 2 shows these stages and the likely progression through them, together with some arrows that represent the cycling, iterative nature of the process.

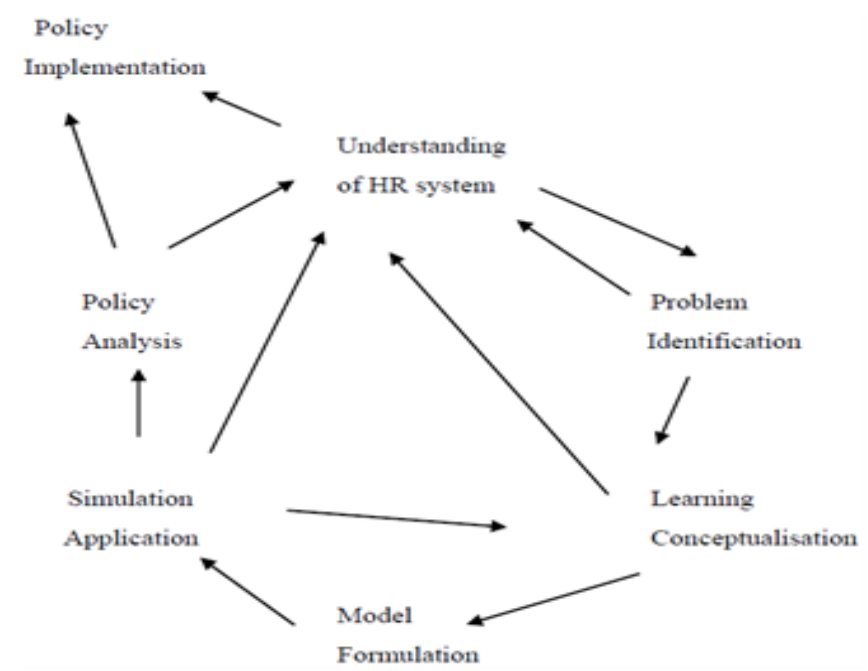

Fig2. Overview of the system dynamics approach

In this system dynamics, systems are seen as composed of a number of interlinked feedback loops. Many relationships between variables in human resource development (HRD) processes are nonlinear. The combination of feedback loops with delays and non-linear relationships gives rise to a wide variety of behavioural characteristics of systems. It is the combination of feedback with delays and non-linearity that can produce unexpected or counterintuitive actual behaviour.

\section{The Development Situation of Public Service System in Korea}

Competency management in the Korean government was considered as one part of reform strategies 
designed to strengthening government competitiveness and in improving government performance (Kim, S. \& Jung, H, 2010). A civil service system of the Korea is focused on for fostering competent and trusted public officials.

The Ministry of Personnel Management (MPM) is now the central agency in charge of the personnel management of Korea's public service. In setting its personnel management policy vision as 'fostering capable and trustworthy public servants,' MPM has introduced core personnel policies and principles. At the same time, the ministry is committed to eliminating personnel management regulations that hinder free and creative personnel management. Accordingly, the Korean government seeks capable candidates with dreams and passions to be public officers through fair and efficient recruitment procedures. The major principles include the following:

- Open competition/Fair process- based on equal opportunity, non-discrimination in terms of educational background, gender or age

- Merit system- based on abilities, qualification and various exam results

- Affirmative action- toward equal opportunity regardless of gender, disability, or income.

As an education endeavor, MPM provides opportunities for public officials to develop their job competencies, cultivate their public office values, and develop themselves all the time. By using IT infrastructure, the ministry provides an environment in which trainees can learn without being constrained by space and time, and operates a constant learning system.

For off-line education, MPM provides also a variety of programs designed to cultivate the competencies and foster the qualities required of public officials, and to develop the professional knowledge necessary for their given duties and understanding of government administration.

\subsection{Enhanced Competency- And Performance-Oriented Personnel Management System}

Enhanced competency- and performance-oriented personnel management is implemented. The MPM has recently implemented new policy initiatives related to personnel management to ensure fairness, openness, efficiency, and higher performance in the public service.

The ministry has integrated and reduced the number of grade levels to improve flexibility in personnel management, and has introduced a new pay scale based on competency and performance. Also, it has improved the process used to manage low-performing high-ranking officials. In addition, it has introduced a fully fledged performance-based salary system (applied down to grade 5 officials) and increased the proportion of performance-based pay. Finally, the ministry has established a differentiated pay scale based on the degree of value being added by jobs.

In addition, MPM is promoting recruitment from the private sector, the hiring of experts through the expansion of career-based job postings in each government agency, and the hiring of experienced global talent in order to secure the best and the brightest. In line with this effort, the Ethics Charter on Civil Servants, which was enacted in 1980, was amended and renamed the Charter of Civil Servants in 2015. Government employees' personnel cards were also changed: personal information such as educational background and body height and weight were eliminated. On top of that, evaluation ratings were used for performance appraisals, and the percentage of the evaluation that is based simply on the number of years of work experience was reduced from $30 \%$ to a maximum of $20 \%$.

\subsection{The Act on Public Officials Education and Training}

The Act on Public Officials Education and Training is amended and renamed the Act on Public Human Resources Development. Today's education for public officials in Korea is being transformed from fragmentary and management-oriented training into human resources development that combines both on-the-job training and self-development.

An HRD network that promotes inter-ministerial cooperation in the field of public HRD and provides access to educational resources on a nationwide basis is being built. Thus, streamlined one-top service in public HRD is being activated by opening all training courses to all public officials; sharing best educational programs, instructors, and facilities; and allowing access to and sharing of training and development information through an integrated education information system.

As part of this effort, MPM amended the Act on Public Officials Education and Training (1973) and renamed it the Act on Public Human Resources Development. The amended act states that the goal of 
HRD is to "develop human resources equipped with appropriate perspectives on public service values and with future oriented competency and expertise," in other words, officials who meet the general public's expectations and are responsive to changes in the times. The new Act also specifies public officials' obligations for self-development and provides a legal ground for self-initiated learning that will improve the creativity and professionalism of public officials.

\subsection{New National Civil Service Education System}

Former COTI (Central Officials Training Institute) was restructured and renamed the National Human Resources Development Institute (NHI).

Government innovation started with human resources innovation, and the development of high-calibre human resources is a driving force of human resources innovation. Future talents fostered in accordance with the new Act on Public Human Resources Development should stand in the vanguard of the innovation of the Korean government and in the enhancement of national competitiveness.

The restructuring and relaunch of the Central Officials Training Institute as the National Human Resources Development Institute is at the core of the new Act. It is hoped that NHI will grow into a leading HRD institute that will play a proactive role in initiating innovation in the training of public officials and spark a paradigm shift in HRD.

NHI is expected will play a more extensive role as the national training and education hub by setting standards in public service values and leadership; engaging in the research, development, and evaluation of training courses for public officials' competency development; and leading exchange and cooperation activities with public and private training and research institutes at home and abroad.

NHI will be reborn as the hub of HRD 3.0 (a new HRD paradigm, introduced by the Korean government, that promotes active sharing of public information and removal of barriers existing among government ministries for better collaboration) by developing high-quality educational programs, promoting research and development that fully reflect trends, and strengthening cooperation with other organizations in Korea and abroad.

In conclusion, despite its already high reputation, NHI has recently gone through major reform in its bid to become one of the world's top HRD institutes, an institute that fosters Korean public officials into the best talents, and an institute that spreads public service values, leadership, and competency development programs to other domestic and foreign institutes.

NHI's Vision and Implementation Strategy

\begin{tabular}{|c|c|c|}
\hline & Vision & Cradle of government officials who can lead the way into a new era for the Republic of Korea \\
\hline & Mission & Training government officials who will lead change and innovation efforts \\
\hline \multicolumn{3}{|r|}{$\Delta$} \\
\hline & $\begin{array}{l}\text { Upgrading education on } \\
\text { public service values to } \\
\text { cultivate trustworthy } \\
\text { government officials }\end{array}$ & $\begin{array}{l}\text { 1. Establish role models for future-oriented government officials } \\
\text { 2. Enhance our education to strengthen public service values } \\
\text { 3. Develop and provide a standardized education program on public service values }\end{array}$ \\
\hline & $\begin{array}{l}\text { Remodeling the } \\
\text { government's HRD system } \\
\text { to produce proactive } \\
\text { government officials }\end{array}$ & $\begin{array}{l}\text { 4. Remodel the framework for standardized education for each career level } \\
\text { 5. Expand the training of managerial officials, focusing on performance } \\
\text { 6. Strengthen purpose-oriented work competency training }\end{array}$ \\
\hline 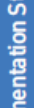 & $\begin{array}{l}\text { Expanding global education } \\
\text { to foster global-minded } \\
\text { government officials }\end{array}$ & $\begin{array}{l}\text { 7. Enhance our global education system to strengthen global competitiveness } \\
\text { 8. Expand the training of foreign government officials for bilateral developments } \\
\text { 9. Promote international exchange and cooperation activities }\end{array}$ \\
\hline 亗 & $\begin{array}{l}\text { Creating integrated } \\
\text { synergy by becoming } \\
\text { as HRD hub for } \\
\text { government officials }\end{array}$ & $\begin{array}{l}\text { 10. Establish good governance based on cooperation among the private, public, } \\
\text { academic, and research sectors } \\
\text { 11. Become an HRD hub for government officials education and training institutes } \\
\text { 12. Expand infrastructure to provide more e-learning programs and self-directed learning }\end{array}$ \\
\hline & $\begin{array}{l}\text { Becoming one of the } \\
\text { world's best public } \\
\text { HRD centers }\end{array}$ & $\begin{array}{l}\text { 13. Strengthen the capacity of the officials who work at NHI } \\
\text { 14. Establish an effective dual campus system (Jincheon and Gwacheon } \\
\text { campuses) after relocating the NHI headquarters to Jincheon } \\
\text { 15. Enhance government officials professionalism and individual capacities }\end{array}$ \\
\hline
\end{tabular}


NHI's 2018 Programs at a Glance

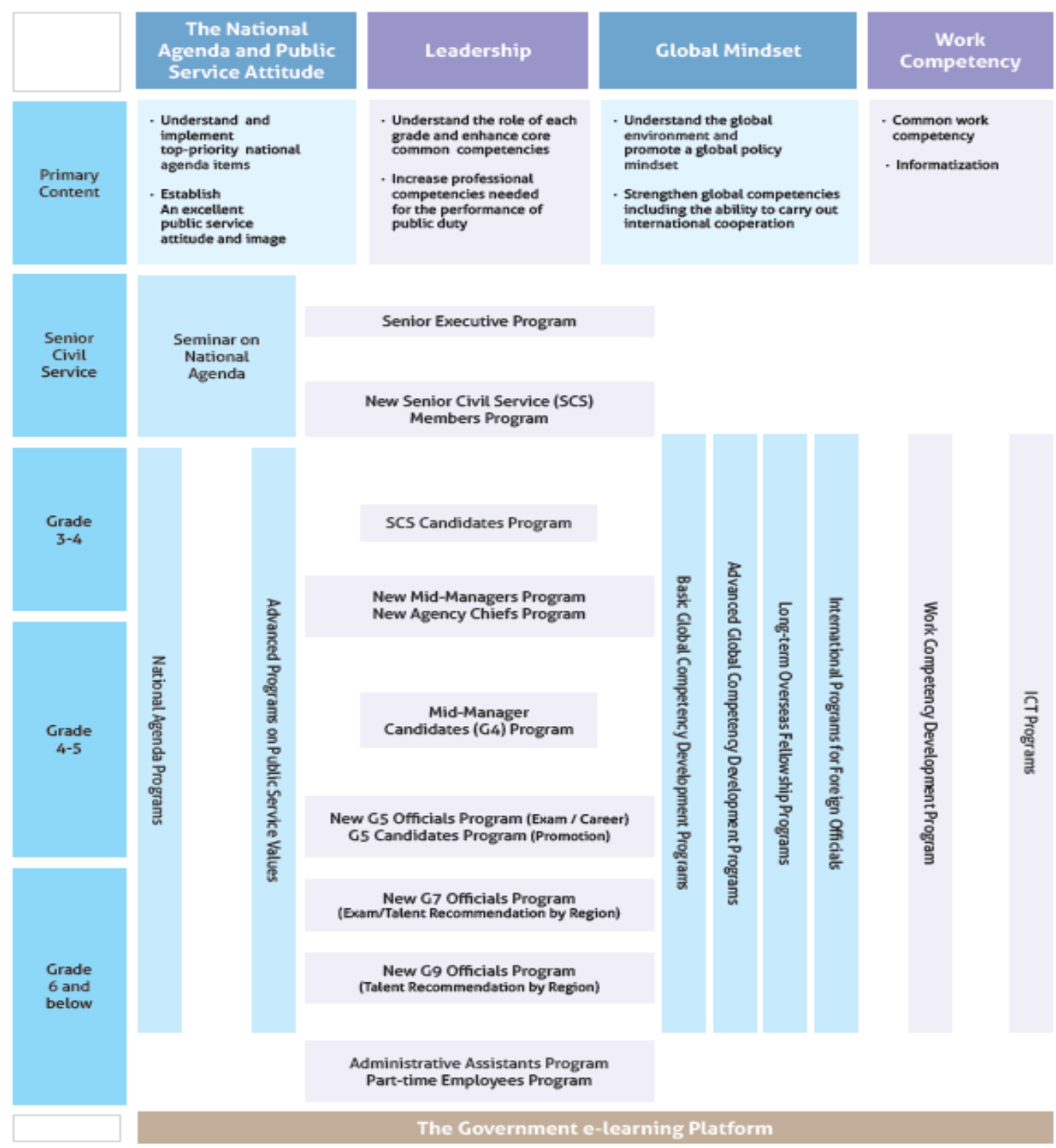

\section{Directions for Civil SERVice EduCATION Programs in the Future}

\subsection{Enhancing Education on Public Service Values}

Enhancing education on public service values is trying to ensure a trusted public service. NHI will strengthen its periodic, repeated, and role-specific education on public service values to ensure participants internalize and put the values into practice. Specifically, the percentage of education on public service values in the grade-based training programs was expanded from $25 \%$ to more than $30 \%$.

Intensive education on public service values was also made available to in-service government employees by conducting advanced courses on job field and highly participatory small group class sessions. At the same time, NHI is providing other training institutes with the foundation for education on public service values.

NHI seeks to disseminate public service values among high-ranking officials who are responsible for policy initiatives. To this end, NHI takes a role as the venue where deputy vice minister- and director general-level officials from central government agencies share public service values and the current administration's governing philosophy and policy directions.

\subsection{Restructuring Training System at Central Government}

Restructuring training is being done to ensure a pioneering public service. NHI pushes ahead with career stage-specific training. As an example, training in leadership skills and in public service values is being provided to officials from the Senior Civil Service (SCS) down to Grade 5. 
Competency development training for SCS and director candidates involves the following: strengthening the connection between pre-training, offline training, and post-training; providing customized competency training; and preparing a standard format for feedback on simulation exercises.

Participants get opportunities for self-recognition as they analyze their individual strengths and weaknesses by using various tools such as a leadership style diagnosis. Programs available to G5 officials (both those newly recruited through the civil service examination and those recruited from the private sector) focus on instilling public service values, leadership skills, and a global mindset. Inservice training for general staff grade 6 or lower is also strengthened to foster capable working-level administrators.

Likewise, performance-based training for managerial officials has been enhanced. The Senior Executive Program (SEP) has been reformed, with the aim of upgrading the qualifications of the participants to the top level. Newly recruited G5 officials who can work effectively in the field immediately after completing training programs are fostered as well.

Purpose-oriented, job-specific competency development programs are also provided; specifically, training on common core job competencies, which is designed to improve job performance and professionalism.

As for training methodology, the range of participatory training based on discussions, practice, and case studies will be expanded, thereby enhancing the applicability of learning results into field work. In particular, future-oriented organizational activation education will be provided to ensure that enhanced competencies related to creativity, sensitivity, and communication can lead to improved job performance and improved organizational cultures. Training programs that reflect the latest trends and practical cases at home and abroad are being conducted in a participatory and interactive way.

The range of training programs that seek to promote an informatization mindset among government officials is being expanded. For example, training programs aimed at spreading a software-based mindset in the government sector are being conducted for the first time. Also, the portion of computer literacy education for managerial officials within grade-based programs, such as those programs on the latest ICT trends and information security, is being increased.

To upgrade education that aims to improve the computer literacy of public officials, intensive training on improving problem-solving skills and job efficiency through the utilization of information technology is being conducted. Moreover, education on essential work systems involving personnel affairs, pay, and public service ethics is being offered. Finally, specialized ICT courses are being systemized according to level of difficulty.

\subsection{Expansion of Infrastructure in e-Learning Contexts}

Expansion of infrastructure for common use of e-learning and for self-initiated learning is being made. E-learning programs that allow for self-initiated learning are provided year-round, as NHI's learning system is not restricted by time, place, or the number of participants.

More specifically, courses that can be customized by the user, such as G-MOOC (GovernmentMassive Open Online Courses) and G-OCW (Government- Open Course Ware), are being provided. The courses are based on the latest education techniques. NHI's year-round learning system for talent development is supported by self-directed learning that is available anytime, anywhere.

NHI's next-generation integrated e-learning system development project will continue. The ICTbased system will provide individually customized e-learning services. In addition, an e-learning system platform will be established. NHI will seek to maximize the effectiveness of e-learning by sharing both the system and platform with other training institutes.

Computer literacy courses will be also strengthened: courses designed to improve the basic computer literacy of officials who have talent in information technology will be expanded; information technology courses for establishing and sharing informatization policy directions will be further specialized; diverse educational content will be secured to enhance the applicability of ICT into field work through e-Learning; and an information utilization course with a focus on highly applicable useful information will be provided.

\section{3-1 e-Learning, the Best Way for Self-Development by Public Officials}


In the past, even when there was an urgent or immediate need for education and training to enhance the capabilities of government organizations or individual officials, only a part of the organization or a few selected officials could benefit from some form of collective training programs, largely due to limits related to work environments or time and space constraints. Subsequently, to help meet the needs that the entire public officials have for training, NHI adopted e-learning utilizing sophisticated IT technology, and then established and developed e-learning system and educational content, respectively. In addition, NHI has provided a mobile e-learning service since 2013, allowing public officials easy access to learning, even on the go.

$<$ The current status of e-learning>

Now public officials can access e-learning system via web or mobile to register for membership, get information on e-learning courses, sign up for/cancel courses, take courses, and check the learning progress and completion. Also, regardless of whether they sign up for e-learning courses, they can use OCW (Open Course Ware).

Apart from these courses, NHI also sets up preliminary courses, called "Blended Learning", for regular courses to help participants quickly absorb the target content and thereby achieve the educational objectives of courses.

Also, certain courses and major government policies deemed worthy of prompt sharing and spreading to the public have been made publicly available on the e-learning system homepage by NHI so that anyone can access the content without logging in. As of Dec. 2015, NHI provided a total of $161 \mathrm{e}$ learning courses under the e-learning system, with some 110,000 officials having completed courses and about 148,000 officials accessing Open Study for self-learning.

$<$ Joint use of the e-learning system>

In the past, public officials could benefit from e-learning courses in enhancing work competency and self-development. E-learning system was, however, set up and administered separately by individual government agencies, central or local, it led to a tremendous amount of budget expenditure involving system setup, content development, administration and maintenance, and system administrator.

Recognizing and addressing this problem, NHI set about integrating e-learning systems to form an elearning center for public officials so that any public official can benefit from high quality learning for free - anywhere, anytime. This move has led to an enormous amount of government budget savings.

It is required for a government agency that would like to utilize the integrated e-learning center to send an official document to NHI' e-learning center. NHI then provides the agency with the indispensable infrastructure for e-learning, including the system, content, and a homepage - all for free. With this support, central and local administrative agencies and training institutes can run their own e-learning courses.

<Achievements of the e-learning system>

Since 2000, when the e-learning system and content were implemented, the number of member institutions joining the system has been on the rise consistently.

As of Dec. 2015, a total of 106 related departments at 85 training institutes, including the Korea Human Resource Development Institute for Health \& Welfare, the Audit and Inspection Training Institute, and the Anti-Corruption Training Institute (under the Anti-Corruption and Civil Rights Commission), have registered some 2,000 pieces of content to provide e-learning courses to approximately 1.3 million officials on an annual basis.

With the joint use of the e-learning system among public-sector training institutes, e-learning has become a major source of training and education for public officials. In fact, more than $90 \%$ of public official training takes place via e-learning.

$<$ Future directions of the e-learning system>

The e-learning system is now sixteen years old, and has a growing number of member organizations. During peak season, when there is high demand for training, some training courses have not been available at times, due to capacity shortage and the inability to incorporate state-of-the-art technology in the aging system to offer the best training services. 
Recognizing this system resource issue, NHI has had consistent consultation with the National Computing and Information Service, which is in charge of integrating and managing government system resources, to convert the existing system to a cloud environment, where resources can be either borrowed or lent among NHI and other training institutes depending on the supply and demand of resources. This transition will enable the seamless operation of e-learning courses.

Moreover, NHI has been now mapping out a three-year master plan to build a next-generation integrated e-learning system, with a view to providing cutting-edge, IT-supported e-learning services and offering a better e-learning environment customized to the differing needs of individual training institutes.

In 2015, in the first phase of the master plan, BPR/ISP (Business Process Reengineering / Information Strategy Planning) was used to incorporate the latest smart learning methods and to design a target model for joint use of the e-learning system, while a pilot NHI e-learning system and a portal to support live streaming of e-learning courses were implemented. Based on that infrastructure, a new form of e-learning services, including G-MOOC and G-OCW, is currently in operation.

The second phase of the plan had put into operation in 2016. Utilizing the progress made in the first phase, NHI planned to set up a more flexible and scalable e-learning platform for joint use and to expand e-learning service function aimed at supporting learning for self-development, thereby providing central and local government agencies with the latest and best e-learning environment.

In the third phase, in 2017, NHI is applying to use the big data accumulated to date to build a personalized e-learning system and an education policy-support system, thereby aiming to set global standards for government training services.

To this end, NHI works to ensure that its efforts to build a next-generation integrated e-learning system comply with international e-learning technology standards and web standards interoperability, and applies an e-government framework so that other countries can adopt its model without separate adaptation efforts.

\section{Next-generation Integrated E-learning System Development Plan}

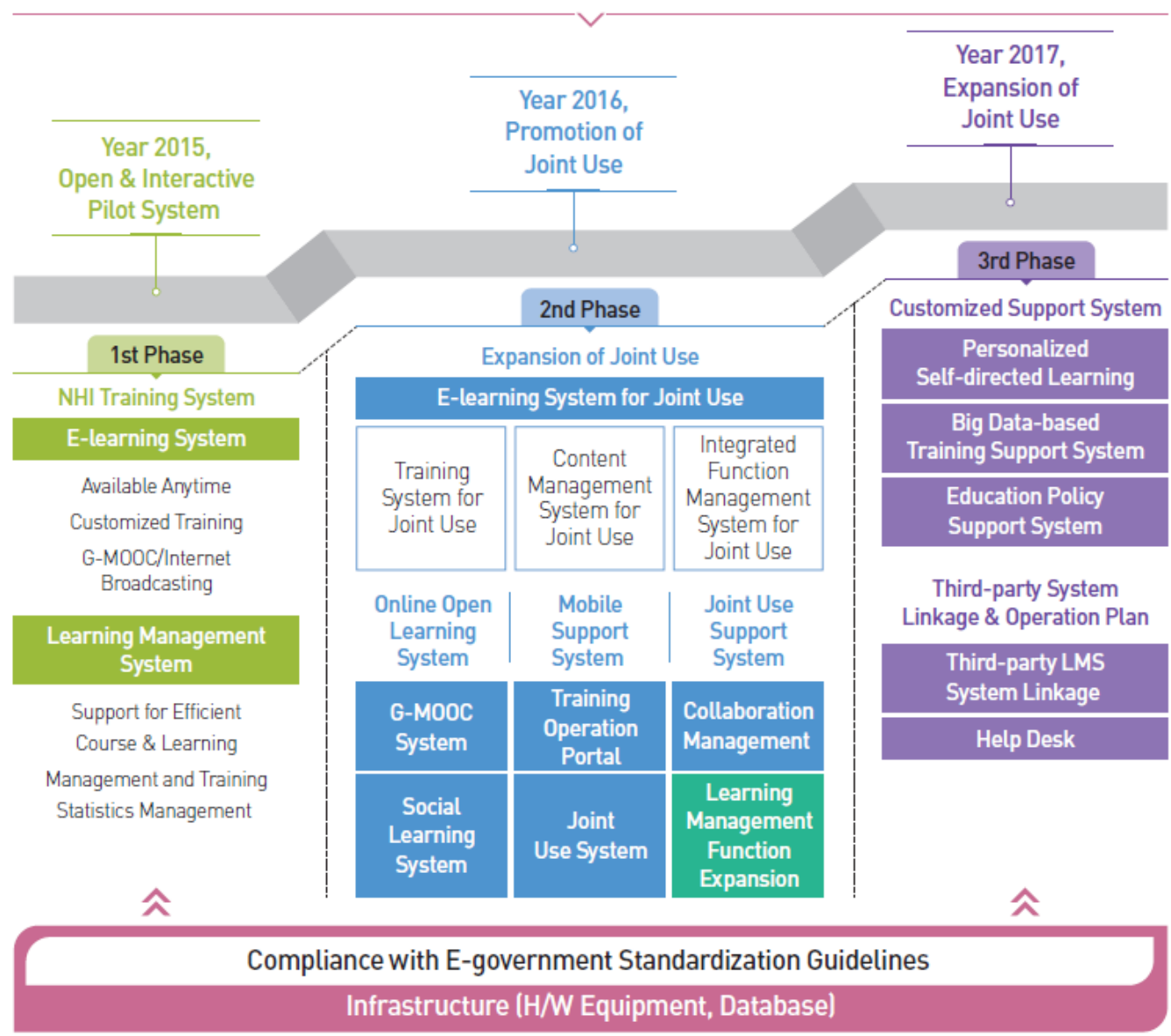




\section{CONCLUSION AND IMPLEMENTATIONS}

Above all, it is important to understand what high performance in the public sector is, and to identify the best civil servants, and their skill, attitude. For the further development we are going to expand the "learn wherever, whenever" system through the use of advanced IT infrastructure etc.

Also, as a vision beyond the limit, in order to foster world-class public officials who will be able to cope with future challenges, we will try to have more creative, responsive and proactive civil servants built on the public's trust.

With relation to these needs for public service system, to deal with current challenges, the Korean government including MPM and NHI etc. plans to develop and implement these policies:

- Keep sustainable growth through talents human resource development

- Achieve public service delivery innovation and social cohesion

- Remove barriers through the opening and sharing of communication inside and outside of public offices

- Help public officials strike a balance between work and life

- Provide efficient IT-based mobile administration

- Lead cross-national development and multi-cultural society through joint efforts

We also sincerely plans to propagate best practices through exchanges and cooperation with a variety of international organizations including the OECD Global Network of Schools of Government.

\section{REFERENCES}

[1] Bacon, N. (2015) "Exploring High Performance Work Systems and Performance, Human resource Management Journal, John Wiley \& Sons, USA.

[2] Choi, J. H. (2014) "The Leadership Competency Development Program 2014," COTI HIGHLIGHT, Vol.24, pp.12-13. COTI, Seoul, Korea.

[3] Choi, Y. M. (2013) "Competency Training Programs," COTI HIGHLIGHT, Vol. 23, pp. 20-21. COTI, Seoul, Korea.

[4] Hwang, I. P. (2016) “NHI's Education and Training Direction,” NHI HIGHLIGHT, Vol. 26, pp. 4-11. NHI, Seoul, Korea.

[5] Hwang, I. P. (2016) "Thoughts on NHI and its Role in the World," NHI HIGHLIGHT, Vol. 26, pp. 76. NHI, Seoul, Korea.

[6] Hwang, I.P. \& Lee, C. et al. (2017) "Evaluation Training Program Using the Success Case Method: Case Study of Korean Public Sector," 2017 AHRD International Research Conference in the Americas, San Antonio, Texas, USA.

[7] Kim, S. \& Jung, H. (2010) The Competency Management in the Korean National Government, K.U. Leuven, Public Management Institute, Belgium.

[8] Ministry of Security and Public Administration, Korea. (2014) The Civil Service System of The Republic of Korea for Fostering Competent and Trusted Public Officials, MOSPA, Seoul, Korea.

[9] NHI (2016) "e-learning, the Best Way for Self-Development by Public Officials," NHI HIGHLIGHT, Vol. 26, pp. 56-58. NHI Publishing, Seoul, Korea.

[10] Richardson, G. (1991) Feedback Thought in Social Science and Systems Theory. Philadelphia, University of Pennsylvania Press, USA.

[11] Seyed K. V. \& Hwang, I. P. (2016) Entrepreneurship and Innovation Policy and Training Systems, Korea Foundation for Advanced Studies, Seoul, Korea.

[12] Snell, S. \& Bohlander, G. (2014) Managing Human Resources, South-western College Pub, USA.

[13] Yoon, B. S. \& Hwang, I. P. (2014) A Competency-based Training Program of the Korean Civil Service, COTI co-working paper, MPM, Seoul, Korea.

\section{AUTHOR'S BIOGRAPHY}

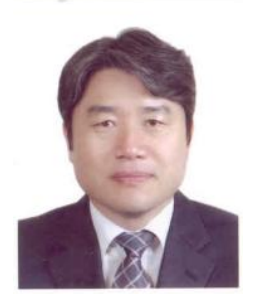

Prof. Hwang, In-Pyo, National Human Resources Development Institute (NHI), Ministry of Personnel Management (MPM), Korea. The work currently is focused on leadership, managerial strategy and HRD/HRM after joined in the NHI on 2005, Ph.D., University of York, UK, MA, ChungAng University, Korea, Post-doctorate, University of Birmingham, UK. Senior specialist, Korea Institute of Science and Technology(KIST). Professor, Kwangju Women's University, Korea. Visiting 
professor, Wharton School, UPenn, California State University, Fresno. USA. Books; 'Leadership in Public Sector', 'Organizational Change and Value' 'Managing for Job Performance'

Citation: In Pyo-Hwang. "Changes in the Korean Government's HR System and in the Education of Government Officials" International Journal of Managerial Studies and Research (IJMSR), vol 6, no. 9, 2018, pp. 44-53. doi: http://dx.doi.org/10.20431/2349-0349.0609005.

Copyright: (C) 2018 Authors. This is an open-access article distributed under the terms of the Creative Commons Attribution License, which permits unrestricted use, distribution, and reproduction in any medium, provided the original author and source are credited. 